\title{
Epilepsy and acute traumatic intracranial haematom产
}

\author{
BRYAN JENNETT \\ From the University Department of Neurosurgery \\ and The Institute of Neurological Sciences, Glasgow
}

SYNOPSIS Acute intracranial haematoma significantly increases the incidence of traumatic epileps鹉 both early (first week) and late. Early epilepsy can cause diagnostic and management problems, while late epilepsy may produce persisting disability.

A pilot study of traumatic epilepsy after nonmissile injuries indicated that acute intracranial haematoma was an important predisposing factor (Jennett and Lewin, 1960). The numbers were small but a much larger series has now been accumulated from various sources, as described in detail elsewhere (Jennett, 1973, 1975). These additional patients were shown not to differ significantly from the original series, which came from an unselected series of head injuries (Table 1). It seems reasonable, therefore, to regard the series as a whole as a valid sample of patients with acute intracranial haematoma. This term was applied if operative drainage was performed within 14 days of injury. Chronic subdural haematoma was excluded from the study, as were birth injuries; there were few infantile haematomas (less than $5 \%$ of the series were under 2 years of age). Traumatic epilepsy was diagnosed if the patient had even one fit, but in the event it

TABLE 1

FREQUENCY OF FEATURES IN PATIENTS WITH HAEMATOMA IN ORIGINAL SERIES OF UNSELECTED INJURIES AND IN ADDITIONAL CASES

\begin{tabular}{|c|c|c|c|c|c|}
\hline \multirow[t]{2}{*}{ Feature } & \multicolumn{2}{|c|}{$\begin{array}{c}\text { Original series } \\
58\end{array}$} & \multicolumn{2}{|c|}{$\begin{array}{c}\text { Additional cases } \\
362\end{array}$} & \multirow[t]{2}{*}{$P$} \\
\hline & (No.) & $(\%)$ & (No.) & $(\%)$ & \\
\hline $\begin{array}{l}<16 \text { years } \\
\text { Extradural } \\
\text { PTA > } 24 \text { hours } \\
\text { Early epilepsy }\end{array}$ & $\begin{array}{l}9 \\
23 \\
24 / 42 \\
13\end{array}$ & $\begin{array}{l}16 \\
40 \\
57 \\
23\end{array}$ & $\begin{array}{l}59 \\
123 \\
168 / 346 \\
99\end{array}$ & $\begin{array}{l}16 \\
34 \\
49 \\
27\end{array}$ & $\begin{array}{l}\text { NS } \\
\text { NS } \\
\text { NS } \\
\text { NS }\end{array}$ \\
\hline
\end{tabular}

(Accepted 22 November 1974.)
TABLE 2

EFFECT OF HAEMATOMA ON INCIDENCE OF EARLY EPILEPSY

\begin{tabular}{|c|c|c|}
\hline & (No.) & $(\%)$ \\
\hline $\begin{array}{l}\text { No haematoma } \\
\text { Intracranial haematoma }\end{array}$ & $\begin{array}{r}33 / 928 \\
112 / 420\end{array}$ & $\begin{array}{r}4 \\
27\end{array}$ \\
\hline $\mathbf{P}$ & $<0$. & \\
\hline
\end{tabular}

was unusual for a patient to have only a fit. Epilepsy which occurred in the first week was termed early, and if after that late; some patient had both early and late epilepsy. If any of the seizures suffered by a patient had any evidencE of focal signs, even at the beginning of a fit, the that patient was regarded as having focal epi lepsy; others were classified as suffering from non-focal epilepsy.

EARLY EPILEPSY This was significantly morê common after injuries associated with acute haematoma (Table 2). The incidence was simila? in adults and children (including those under five. years of age), and whether or not post-traumatio amnesia (PTA) was prolonged or there were focat neurological signs (Table 3). Patients with only an extradural haematoma had a significantly lower epilepsy rate than those with intradurâ haematomas (Table 4); subdural and intra? cerebral haematomas were similar. Rather morf than half the patients had some fits with a focad component, and about one patient in 10 develo oped status epilepticus. Early epilepsy associate 378 
TABLE 3

INCIDENCE OF EARLY EPILEPSY AFTER ACUTE INTRACRANIAL HAEMATOMA WITH VARIOUS FEATURES

\begin{tabular}{lccccc}
\hline & \multicolumn{4}{c}{ Feature } & \multirow{2}{*}{$P$} \\
\cline { 2 - 5 } & \multicolumn{2}{c}{ Present } & \multicolumn{2}{c}{ Absent } & \\
& $(N o)$. & $(\%)$ & $(N o)$ & $(\%)$ & \\
\hline$<5$ years & $9 / 28$ & 32 & $103 / 392$ & 26 & NS \\
>16 years & $95 / 352$ & 27 & $17 / 68$ & 25 & NS \\
PTA $>24$ hours & $62 / 210$ & 30 & $36 / 136$ & 26 & NS \\
Focal signs & $50 / 175$ & 29 & $62 / 245$ & 25 & NS \\
\hline
\end{tabular}

TABLE 4

INCIDENCE OF EARLY EPILEPSY WITH ACUTE HAEMATOMA IN DIFFERENT SITES*

\begin{tabular}{lll}
\hline & $($ No. $)$ & $(\%)$ \\
\hline Extradural only & $15 / 146$ & 10 \\
Intradural & $76 / 219$ & 35 \\
\hline$P$ & $<0.001$ \\
\hline Subdural & $58 / 159$ & 36 \\
Intracerebral & $18 / 60$ & 30 \\
\hline$P$ & \multicolumn{2}{c}{ NS } \\
\hline
\end{tabular}

* Excluding patients with haematoma at more than one site.

TABLE 5

TIME AFTER INJURY OF FIRST EARLY FIT WITH ACUTE HAEMATOMA

\begin{tabular}{|c|c|c|c|c|c|c|c|}
\hline & & \multicolumn{2}{|c|}{ First hour } & \multicolumn{2}{|c|}{ 1-24 hours } & \multicolumn{2}{|c|}{$>24$ hours } \\
\hline & & (No.) & $(\%)$ & (No.) & $(\%)$ & (No.) & $(\%)$ \\
\hline Haematoma & 108 & 11 & 10 & 23 & 21 & 74 & 69 \\
\hline No haematoma & 321 & 107 & 35 & 119 & 37 & 95 & 30 \\
\hline $\mathbf{P}$ & & \multicolumn{2}{|c|}{$<0.001$} & \multicolumn{2}{|c|}{$<0.01$} & \multicolumn{2}{|c|}{$<0.001$} \\
\hline
\end{tabular}

with haematoma was often delayed for more than 24 hours after injury and this was significantly different from the time of onset of early epilepsy after other types of injury (Table 5). This suggests that the epilepsy is often associated with the development of the haematoma; but in a third of cases epilepsy first appeared only after the haematoma had been evacuated (Table 6).

SIGNIFICANCE OF EARLY EPILEPSY AS SIGN OF
DEVELOPING HAEMATOMA The question is often asked whether the development of epilepsy is in itself important evidence in favour of this complication. Although acute intracranial haematoma is much more consistently associated with other features-in particular, deterioration of the level of consciousness-epilepsy is such a dramatic event that not infrequently this is what draws attention to this complication. In the unselected Oxford series $28 \%$ of patients with early epilepsy proved to have an intracranial haematoma; two-thirds of these patients had acute subdural clots, a half of whom developed early

TABLE 6

EARLY EPILEPSY IN RELATION TO OPERATION FOR ACUTE HAEMATOMA

\begin{tabular}{lcc}
\hline & $($ No. $)$ & $(\%)$ \\
\hline Only before & 50 & 56 \\
Only after & 30 & 34 \\
Both & 9 & 10 \\
\hline All before & 59 & 66 \\
All after & 39 & 44 \\
\hline
\end{tabular}

epilepsy. Such patients are usually already seriously ill, with focal signs and altered consciousness; the occurrence of epilepsy is therefore an incident of limited diagnostic significance. It is more important to discover how often epilepsy heralds an extradural haematoma, which more often develops after a lucid interval or even when there has been no initial loss of consciousness. Only $10 \%$ of 146 patients with extradural haematoma had early epilepsy and in a third this did not occur until after surgical evacuation of the clot. Of more than 400 patients with early epilepsy less than $2 \%$ proved to be developing an extradural haematoma at the time of their first fit; moreover there were always other signs pointing to this complication. Even among patients who develop early epilepsy after injuries associated with neither initial loss of consciousness nor PTA, a haematoma was found in only a small proportion ( $8 \%$ ). It seems reasonable to conclude that the occurrence of a fit is in itself an insufficient reason for strongly suspecting an intracranial haematoma; if there 
are no other features pointing to this complication epilepsy does not justify further investigation and certainly not exploration.

LATE EPILEPSY Only patients followed-up for more than a year were considered for this part of the study; they were shown not to differ significantly from the original series (Table 7). Late epilepsy was significantly more common than after other types of injury (Table 8), and the incidence was higher after intradural than extradural haematoma (Table 9). The epilepsy rate

TABLE 7

FEATURES OF ORIGINAL HAEMATOMA SERIES AND OF THOSE FOLLOWED

\begin{tabular}{|c|c|c|c|c|c|}
\hline & \multicolumn{4}{|c|}{ Feature } & \multirow{3}{*}{$P$} \\
\hline & \multicolumn{2}{|c|}{$\begin{array}{c}\text { Original series } \\
420\end{array}$} & \multicolumn{2}{|c|}{$\begin{array}{c}\text { Followed-up } \\
128\end{array}$} & \\
\hline & (No.) & $(\%)$ & (No.) & $(\%)$ & \\
\hline $\begin{array}{l}<5 \text { yr } \\
>16 \text { yr } \\
\text { PTA }>24 \mathrm{hr} \\
\text { Extradural } \\
\text { Focal signs } \\
\text { Early epilepsy }\end{array}$ & \begin{tabular}{l}
\multicolumn{1}{c}{28} \\
352 \\
$210 / 382$ \\
146 \\
175 \\
112
\end{tabular} & $\begin{array}{r}7 \\
84 \\
55 \\
35 \\
42 \\
27\end{array}$ & $\begin{array}{c}9 \\
100 \\
79 / 126 \\
59 \\
73 \\
35\end{array}$ & $\begin{array}{r}7 \\
78 \\
63 \\
48 \\
57 \\
57 \\
27\end{array}$ & $\begin{array}{c}\text { NS } \\
\text { NS } \\
\text { NS } \\
\text { NS } \\
<0.01 \\
\text { NS }\end{array}$ \\
\hline
\end{tabular}

TABLE 8

EFFECT OF ACUTE HAEMATOMA ON INCIDENCE OF LATE EPILEPSY

\begin{tabular}{llr}
\hline & $(N o)$. & $(\%)$ \\
\hline No haematoma & $27 / 854$ & 3 \\
Acute haematoma & $45 / 128$ & 35 \\
\hline$P$ & \multicolumn{2}{c}{$<0.001$} \\
\hline
\end{tabular}

did not differ significantly with various features of the injury (Table 10).

Two-thirds of patients with late epilepsy after haematoma had their first fit in the first year after injury. Subdural haematoma was significantly more common in patients whose post-traumatic fit occurred in the second, third, and fourth weeks after injury than when it happened in the first week or after the end of the first month (Table 11). Late epilepsy after haematoma had a focal component in almost $50 \%$ of patients. In cases followed for two years or more after the development of late epilepsy, fits continued at rate of more than one a month in rather mores than a quarter; somewhat more than a third hadf at least two years free of attacks. Howevero epilepsy frequently recurred even after such remission.

TABLE 9

INCIDENCE OF LATE EPILEPSY AFTER HAEMATOMAS IN DIFFERENT SITES*



INCIDENCE OF LATE EPILEPSY AFTER HAEMATOMA WITH DIFFERENT FEATURES

\begin{tabular}{|c|c|c|c|c|c|}
\hline & \multicolumn{4}{|c|}{ Feature } & \multirow{3}{*}{$P$} \\
\hline & \multicolumn{2}{|c|}{ Present } & \multicolumn{2}{|c|}{ Absent } & \\
\hline & (No.) & $(\%)$ & (No.) & $(\%)$ & \\
\hline $\begin{array}{l}\text { Age }<16 \text { yr } \\
\text { PTA }>24 \mathrm{hr} \\
\text { Focal signs } \\
\text { After early epilepsy }\end{array}$ & $\begin{array}{r}7 / 28 \\
33 / 79 \\
29 / 73 \\
9 / 32\end{array}$ & $\begin{array}{l}25 \\
42 \\
39 \\
28\end{array}$ & $\begin{array}{l}38 / 100 \\
12 / 47 \\
16 / 55 \\
36 / 96\end{array}$ & $\begin{array}{l}38 \\
26 \\
29 \\
38\end{array}$ & $\begin{array}{l}\text { NS } \\
\text { NS } \\
\text { NS } \\
\text { NS }\end{array}$ \\
\hline
\end{tabular}

TABLE 11

FREQUENCY OF SUBDURAL HAEMATOMA IN PATIENTS WITH TRAUMATIC EPILEPSY

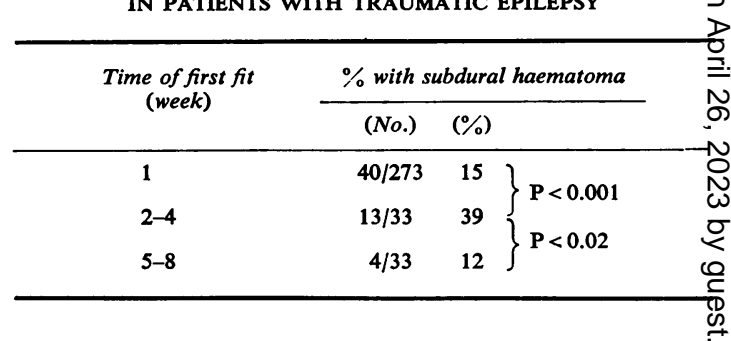




\section{DISCUSSION}

Few reports about intracranial haematoma include any reference to epilepsy; in these a clear distinction is seldom drawn between acute and chronic haematoma, and never between early and late epilepsy. Chronic subdural haematoma, evacuated more than two weeks after injury, is such a different clinical and pathological entity that it was judged wise to exclude it from the present analysis. It is late epilepsy which is of significance for the patient himself, because it tends to persist and can cause appreciable disability even when recovery is otherwise satisfactory.

In the wider study of traumatic epilepsy after non-missile injuries (of which this report is a part) patients with acute intracranial haematoma proved to have the highest risk of developing late epilepsy-considerably higher than those with depressed fracture (Jennett, 1973). The incidence of late epilepsy after acute intradural haematoma is strikingly similar to that reported after penetrating missile injuries of the skull, a rate which has remained constant in spite of improved early management of such injuries in successive wars (Jennett, 1975). The brain damage in the two instances is somewhat similar, consisting of cortical laceration; the $40-50 \%$ risk attaching to this presumably reflects the susceptibility or threshold of the population. The importance of knowing that patients who have survived the evacuation of an acute intracranial haematoma have a high risk of late epilepsy is that prophylactic anticonvulsant medication can be considered. Attention has recently been drawn to the possibility of preventing post-traumatic epilepsy by the early institution of such treatment (Rapport and Penry, 1972, 1973).

This study was supported by the National Fund for Research into Crippling Diseases, and by the British Epilepsy Association. I am grateful to Mr Douglas Miller and Dr Samuel Galbraith for assistance in the collection of data. My colleagues in the Division of Neurosurgery kindly allowed their patients to be included in the study.

\section{REFERENCES}

Jennett, B. (1973). Epilepsy after non-missile head injuries. Scottish Medical Journal, 18, 8-13.

Jennett, B. (1975). Epilepsy after Non-Missile Head Injuries, 2nd edn. Heinemann: London.

Jennett, B., and Lewin, W. (1960). Traumatic epilepsy after closed head injuries. Journal of Neurology, Neurosurgery, and Psychiatry, 23, 295-301.

Rapport, II, R. L., and Penry, J. K. (1972). Pharmacologic prophylaxis of posttraumatic epilepsy. Epilepsia, 13, 295304.

Rapport II, R. L., and Penry, J. K. (1973). A survey of attitudes toward the pharmacological prophylaxis of posttraumatic epilepsy. Journal of Neurosurgery, 38, 159-166. 